\title{
The Comparison of Business Environment in Development Zones: A Study of the China-Laos Economic Corridor
}

\author{
Fangjiu Wang, Hainan $\mathrm{Wu}^{*}$ \\ School of Politics and Public Administration, Soochow University, Suzhou, Jiangsu Province, China 215000. \\ *Corresponding author
}

\begin{abstract}
Economic corridor is an innovative international cooperative framework which has more solid partnership than traditional international relationship. Endowed with special legislative supports from governments, development zones present some certain economic functions in an area and even a country. International cooperative projects usually start from development zones. An evaluation on business environment of development zones become remarkable and significant, and even could be an investment guidance for investors on along countries of economic corridor. This article investigated SIP, as a development zone in the first place in China, and Saysettha, a co-constructed development zone in Laos, and compared the business environment with the World Bank's doing business index system. The result of comparison and analysis might be helpful for both countries to strengthen cooperation through economic corridor framework, and be exemplary for development zones to improve their business environment.
\end{abstract}

Keywords: Economic corridor, Development zone, Business environment

\section{INTRODUCTION}

Since March 2015, the Summit "Vision and Action to Promote the Co-construction of the Silk Road Economic Belt and the $21^{\text {st }}$ World Maritime Silk Road" proposed the construction of the "China-Indochina Peninsula" economic corridor as an important support for the "the Belt and Road initiative", the corridor has made positive progress in infrastructure connectivity and the construction of a cross-border economic cooperation zones. In the second half of 2017, the China-Indochina Economic Corridor had opened a new chapter in the key regions and some important fields, and was subdivided from multi-party cooperation to bilateral cooperation. China and Laos are the first countries to jointly explore the development model. In November 2017, China and Laos published the "China-Laos Joint Statement", proposing to build a China-Laos economic corridor starting from Yunnan Province of China, relying on China-Laos railway and passing through several important node areas. This economic corridor is taken as an important link between China's "the belt and road initiative" and Laos' strategy of turning "land locked country" into "land united country", and is pushed forward the concrete implementation of the Belt and Road Initiative in Laos.

Development zones always play key roles during reforming and opening of a country. In 1992, Pudong new district established, and in 1994, the industrial park of Suzhou (SIP) was founded. Today, there are thousands of development zones with various functions and different levels in China. Laos has set up some development zones as well. For instance, the Mohan-Moding Economic Cooperation Zone, and Saysettha Comprehensive Development Zone, are connected by the China-Laos railway, that is progressing steadily. What's more, the Porofen Comprehensive Development Project and the Digital Industry Base of Golden Triangle Special Economic Zone has brought new energy to the growth of this economic corridor.

SIP was co-established by Singapore and Chinese governments, absorbing experience from Singapore, who achieved the second place in business environment by the World Bank in 2020, while China won the $31^{\text {st }}$ place (World Bank, 2020). SIP has awarded the first prize of economic development zone in China for three years in succession since 2016 (Ministry of Commerce of China, 2019). SIP was evaluated that performed significantly especially in industry development and international trade. The foundation of Saysettha began at 2010. Government of Vientiane signed the capital contribution agreement with Yunnan Construction Investment Group from China. In the next year, it was announced to become a national-leveled special economic zone (Belt and Road Portal, 2017). Till 2018, 45 enterprises from 6 countries have settled in this development zone with sum capital of some 500 million dollars (Belt and Road Portal, 2018).

As a special economic zone that co-constructed by Laos and China, Saysettha has become a milestone of China-Laos Economic Corridor. However, the business environment assessment result of Lao PDR was not so satisfying. It just ranks 154 in 2020 (World Bank, 2020). Therefore, whether the enterprises in the development zone are affected with the host country's business environment, 
how is the individual business environment in the development zones, and what it might reflect to the China-Laos Economic Corridor, will be the research focuses of this article.

The assessment and study onto business environment of an economy or comparison of business environment across countries and regions helps to improve the competitivity of an economy or the related areas. Singapore researchers realized the importance in early years. They (Sim et al, 2003) create an international competitivity pattern for global cities and figure out that Singapore should confront with a greater competition pressure and adjust its strategy of development, to encompass regional synergies with the ASEAN countries, China and India, so as to expand its economic spread. Based on study from the World Bank on poor people, Rocha (2012) emphasizes the importance of SME, which is sophisticated to business environment and contributes to poverty shaking-off for the poor. Some Slovak researchers (Buno et al, 2015) compare innovation, infrastructure, institution and macro economy indexes across countries and offer some countermeasures to SMEs and government in their country. Gaganis and his colleagues (Gagnis et al, 2019) analyzes samples in $25 \mathrm{EU}$ countries to refine the indicators of business environments which affects the profitability of SMEs.

\section{METHODOLOGY}

\subsection{Indexes and Assessment Method}

The World Bank has developed an assessment index for measuring business-environmental levels of 190 economies, including countries and regions with different social systems and religions. Some Chinese local governments have developed an evaluation system for business environment according to business life too. Normally the business life of an enterprise contains four steps, starting, building up, running business and ending business. This article takes World Bank's index and methods as well as the ranking, and might simulate a ranking for the investigated development zones. Since World Banks' indexes cover the whole life a business, the authors re-edit the indexes as a combination. Meanwhile due to some practical or realistic reasons, some indicators might not fit the certain zones, that may be technically skipped or replaced.

The World Bank uses front distance method to assess the values and rank these economies. This article takes the same calculation.

$\mathrm{F}(\mathrm{v})=[\mathrm{V}-\mathrm{V}(\mathrm{b})] /[\mathrm{V}(\mathrm{w})-\mathrm{V}(\mathrm{b})] * 100(1)$ $\mathrm{V}(\mathrm{b})$ refers the best value that the World Bank evaluated from 190 economies on an indicator, while V (w) refers the worst. Such a function distances V (the actual value) from the best, and tells the direction for improving. This article takes $\mathrm{V}(\mathrm{b})$ and $\mathrm{V}(\mathrm{w})$ from doing business reports of the World Bank, for a common base of ranking simulation.

Table 1 Index of evaluation of business environment

\begin{tabular}{|c|c|c|}
\hline Business Life & Index & Indicator \\
\hline \multirow{4}{*}{$\begin{array}{l}\text { Starting } \\
\text { Business }\end{array}$} & \multirow{4}{*}{ Starting a business } & Procedures (numbers) \\
\hline & & Time (days) \\
\hline & & Cost (\% of income per capita) \\
\hline & & Minimum Capital (\& of income per capita) \\
\hline \multirow{12}{*}{ Building Up } & \multirow{4}{*}{ Building permit } & Procedures (numbers) \\
\hline & & Time (days) \\
\hline & & Cost ( $\%$ of warehouse value) \\
\hline & & Building Quality control index (0-15) \\
\hline & \multirow{4}{*}{ Electricity connection } & Procedures (numbers) \\
\hline & & Time (days) \\
\hline & & Cost ( $\%$ of income per capita) \\
\hline & & $\begin{array}{l}\text { Reliability of supply and transparency of } \\
\text { tariff index }(0-8)\end{array}$ \\
\hline & \multirow{4}{*}{ Property registration } & Procedures (numbers) \\
\hline & & Time (days) \\
\hline & & Cost (\% of property value) \\
\hline & & $\begin{array}{l}\text { Quality of the land administration index } \\
(0-30)\end{array}$ \\
\hline Running & Getting credit & Strength of legal rights index $(0-12)$ \\
\hline
\end{tabular}




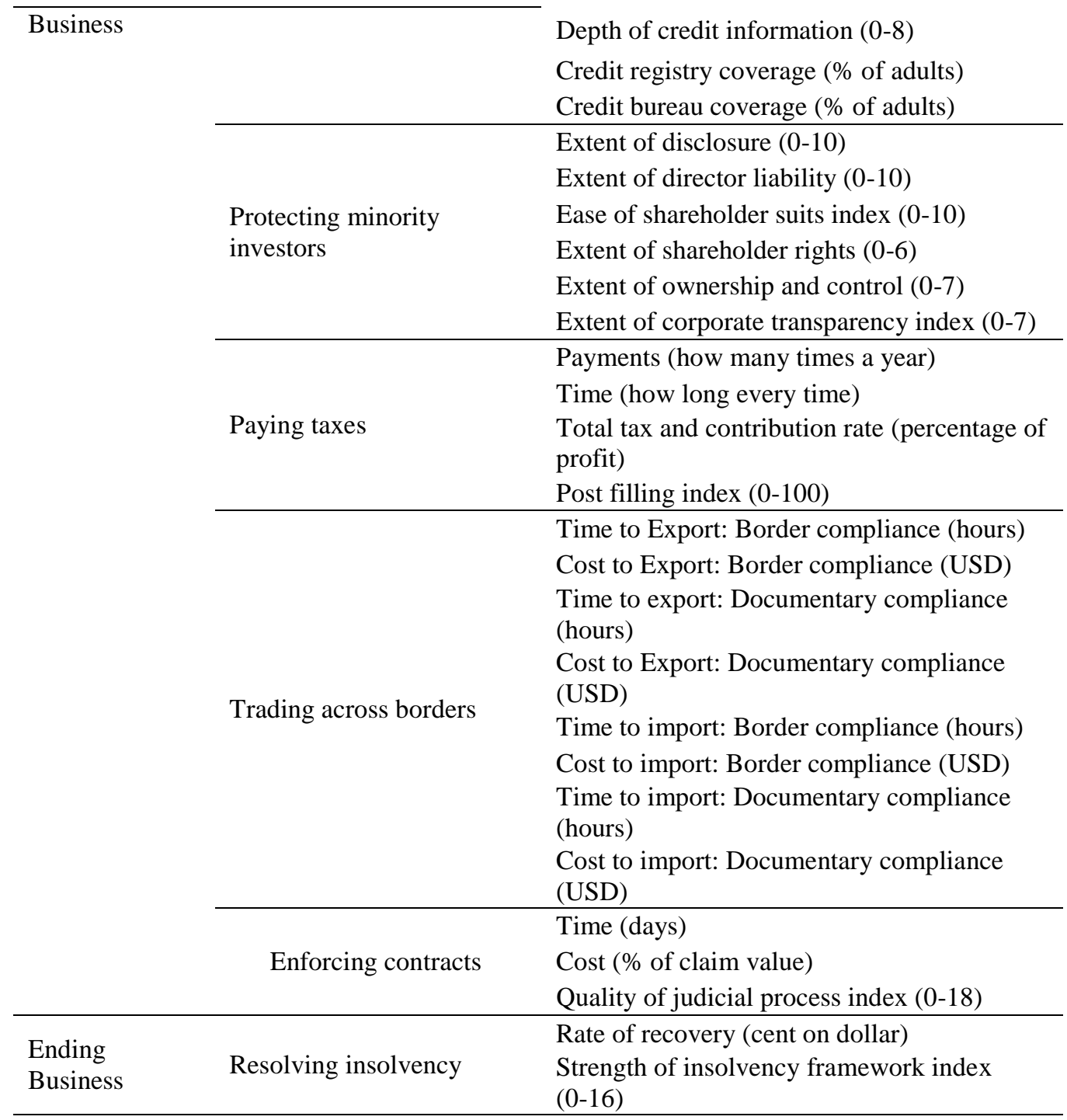

Source: Authors, based on the World Bank, Doing Business indexes, combining with business life.

\subsection{Data Collection}

As a comparison research, this article investigates both SIP, as an example of development zones of China, and Saysettha, example of Laos' development zone, and analyzes their difference in business environment, that contributes to economic corridor construction of both countries.

The data on country level comes directly form World Bank's doing business reports. Data from development zones were collected through investigations. Information from development zones' government or administrative committee, was refined from meetings and interviews, while information from enterprises located in the development zones was combined from questionnaires and free talks.

The investigation on SIP was processed by SIPAC, associating with KPMG. The investigation on Saysettha was executed by the authors under the conduction and support of Saysettha committee.

\subsection{Discussion}

The World Bank's common index makes it possible to simulate a world ranking for the related economies on the same base. 


\section{A simulating world ranking of business environment}

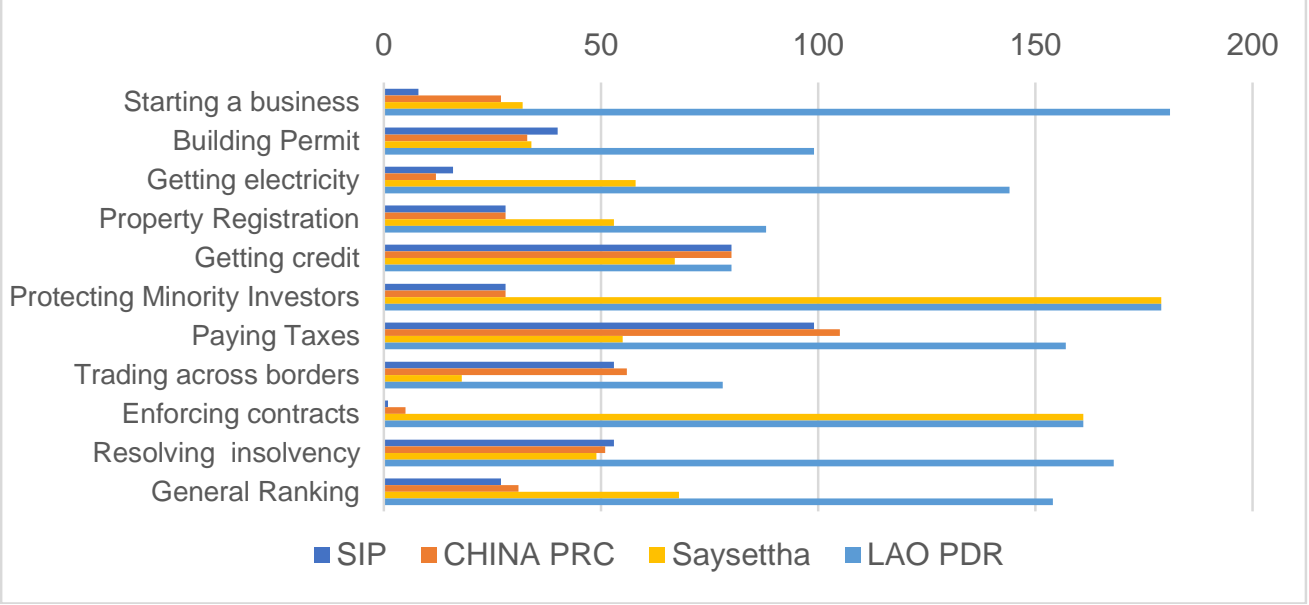

Source: Authors, based on World Bank's doing business reports

Figure 1 A simulated world ranking of business environment of SIP and Saysettha

In general, Lao PDR stands very backward at business environment, while China has improved a lot in the last years and achieved a rank of 31 in 2020. The simulated world ranking of SIP is 27, 4 places forwarder than China. However, the simulated ranking of Saysettha appears far away from country Laos. Saysettha ranks 68 and Laos 154. Most of indexes show that development zones' rankings lean more forward than the countries, especially indexes of starting a business, paying tax, and trading across borders, that reflect the advantage of development zones. However, indexes like protecting minority investors, being of a nation's legal level, and getting credit, as well as enforcing contracts, of a nation's social level, may rank the same or less different between a development zone and its country. Table 2 compares the assessment values of business environment indexes between SIP and Saysettha. Both China and SIP achieve higher score than Laos and Saysettha, the advantage of SIP towards Saysettha is 8.7, while advantage between China and Laos is 27.1. All the indexes in China attained higher scores than Laos except getting credit being equal. However, only 5 indexes that SIP scores higher numbers than Saysettha. Saysettha exceeds over SIP in the other 5.

Difference between both development zones on starting a business is 2.5. SIP takes a lead on procedures and time with its advanced online application system. Saysettha's advantage lays on cost and minimum capital. In Laos, paid-in Capital is allowed to be zero. It is worth mentioning that applied time to register a company in Saysettha is only 15 days under the special support of the committee, that is much shorter than other regions in Laos. Saysettha takes a lead on building permit. The key reason is, Yunnan construction and investment group, Chinese shareholder of Saysettha, is able to be contracted to make construction jobs for the incoming enterprises with professional level. Meanwhile, companies in Saysettha could also optionally decide to lease properties. These bring much advantage to Saysettha comparing with its country Laos.

Table 2 Business environment scores of SIP and Saysettha

\begin{tabular}{lcccccc}
\hline $\begin{array}{l}\text { Business } \\
\text { Environment Index }\end{array}$ & SIP & Saysettha & Difference & $\begin{array}{l}\text { China } \\
\text { PRC }\end{array}$ & $\begin{array}{l}\text { Lao } \\
\text { PDR }\end{array}$ & Difference \\
\hline Starting a business & 96.2 & 93.7 & 2.5 & 94.1 & 62.7 & 31.4 \\
\hline Building Permit & 76.3 & 77.5 & -1.2 & 77.3 & 68.3 & 9 \\
\hline Getting electricity & 92.4 & 82.4 & 10 & 95.4 & 58 & 37.4 \\
\hline Property Registration & 81.4 & 72.9 & 8.5 & 81 & 64.9 & 16.1 \\
\hline Getting credit & 60 & 70.9 & -10.9 & 60 & 60 & 0 \\
\hline $\begin{array}{l}\text { Protecting Minority } \\
\text { Investors }\end{array}$ & 72 & 20 & 52 & 72 & 20 & 52 \\
\hline Paying Taxes & 71.3 & 80.3 & -9 & 70.1 & 54.2 & 15.9 \\
\hline Trading across borders & 87.2 & 98 & -10.8 & 86.5 & 78.1 & 8.4 \\
\hline Enforcing contracts & 90.7 & 42 & 48.7 & 80.9 & 42 & 38.9 \\
\hline
\end{tabular}




\begin{tabular}{lllcccc} 
Resolving insolvency & 61.4 & 62.6 & -1.2 & 62.1 & 0 & 62.1 \\
\hline Business Ease Score & $\mathbf{7 8 . 9}$ & $\mathbf{7 0 . 2}$ & $\mathbf{8 . 7}$ & $\mathbf{7 7 . 9}$ & $\mathbf{5 0 . 8}$ & $\mathbf{2 7 . 1}$ \\
\hline
\end{tabular}

Source: Authors, based on doing business reports from the World Bank

Getting electricity is a disadvantage of Laos, but as a key development zone, Saysettha gets special care, that 189 MVA is installed, and power connection get supported by the committee. SIP scores higher with its electricity marketing distribution. Both development zones still have room for improvement in the reliability of power supply and transparency of tariff index.

Both developing countries are weak at property registration. Saysettha performs better than its country with committee's support in times and land administration indexes. Procedure in SIP contains only 4 steps, taking 9 days, costing $3.8 \%$, that is on an advanced level in the world.

SIP follows national finance system which might not fit World Bank indexes very well that scores 60. Laos performance is not good either, but Saysettha evaluates better with special support from the committee and Chinese banks located.

Minority investors protection is fairly relevant to the legal environment of a country. Both SIP and Saysettha score same with their countries, evaluated 60 and 20, being considerably low performance in the world.

Taxation is normally an advantage of development zones, so are Saysettha and SIP. Tax concession in Saysettha is quite attractive to investors, that is, 5 years free and the latter year $8 \%$, which contributes himself a high score, but its tax paying procedures and time, as well as postfilling index depends on the country and performs unsatisfactory. SIP ends its tax discount policies for years and the comprehensive score lays the middle level in the world. International trading is another advantage of a development zone. Saysettha is treated with free importing tariff for equipment for 8 years, and free exporting tax for materials for 5 years. Meanwhile, Saysettha committee helps for getting the related approvals which saves time for enterprises located. SIP has advantage on time and procedures, but not the costs.

SIP scores well in enforcing contracts, higher than China, while Saysettha was evaluated same low score with Laos. The reason is, after years growing, SIP has developed an advanced and efficient judicial system. Its claim cost is only $9.3 \%$ and judicial quality has reached 16.5 . Saysettha has no individual judicial system, therefore takes score directly from Vientiane.

Both development zones attain similar scores regarding to index of resolving insolvency. SIP performs mildly less than China, because most bankrupted enterprises affiliated to manufactural industries that the fixed assets proportion might be high, so as depreciated value, meanwhile, these labor-intensive factories may spend a lot in severance pay when they get closed. Saysettha performs much better than Laos, the reason was, so far most of enterprises leased land and plant from the committee, labor severance cost in Lao is generally on a low level, and some facilities are able to be sold in the industrial park. However, Saysettha's strength of insolvency framework measures only 8 from a full mark of 16 .

\section{SUMMARY}

Saysettha is an important node of China-Lao Economic Corridor, as well as an example of international cooperation in development zone. According to the World Bank reports, China has improved business environment in last decades, thus with the economic corridor, Lao might be benefited with Chinese experience output, also economic spillover effects (Liang, Shen, 2019). Through the comparison of two remarkable development zones from both countries, the advantage and shortage become revealed.

Laos is weak at infrastructure especially in transportation and communication. Under the support from Chinese partner, Saysettha scores much better than Laos in the related indexes. This experience could be able to spillover to the host city Vientiane, even the country. On contrast, China is strong at infrastructure construction. This implies a direction of further cooperation between two countries. On the other hand, Saysettha is getting strong policy support from Lao PDR, e.g., tax discounting, that would be attractive for Chinese investors. If Laos could improve his legislative and cultural environment to protect foreign investors, the country will be benefited from investors from economic corridor along counties.

Both countries don't perform well at compliance construction. This comparison helps them to discover and realize the problem. It might be direction of common effort that both should work together to overcome through economic corridor framework. What's more, both countries ought to pay attentions to the negative externalities, e.g. the illicit industries (Holden, 2017) and illegal trades (Krishnashamy, Shepherd, 2018), and develop an innovative path based on economic corridor framework and the World Bank's index system.

\section{REFERENCES}

[1] World Bank. Donging business reports 2020. Retrieved February 1, 2020, from http://chinese.doingbusiness.org/zh/data/exploreeconom ies/singapore\#

[2] Ministry of Commerce of China. Ranking of development zones. Retrieved February 1, 2020, from http://www.mofcom.gov.cn/article/ae/ai/201812/201812 02821904.shtml 
[3] Belt and Road Portal. Events 2018-02-03. Retrieved February 1, 2020, from https://www.yidaiyilu.gov.cn/qyfc/xmal/6022.htm

[4] Belt and Road Portal. Events 2018-05-27. Retrieved February 1, 2020, from https://www.yidaiyilu.gov.cn/xwzx/hwxw/56228.htm

[5] World Bank. Donging business reports 2020. Retrieved February 1, 2020, from https://chinese.doingbusiness.org/content/dam/doingBu siness/country///lao-pdr/LAO.pdf

[6] Sim, L., Ong, S., Agarwal, A. Singapore's competitiveness as a global city: development strategy, institutions and business environment. Pergamon-Cities, 20 (2003) 115-127. Doi:10.1016/s0264-2751(02)00119-1.

[7] Rocha, E. The Impact of the Business Environment on the Size of the Micro, Small and Medium Enterprise Sector; Preliminary Findings from a Cross-Country Comparison. Procedia Economics and Finance 4 (2012) 335-349.

[8] Buno, M., Nadanyiova, M., Hraskova, D. The comparison of the quality of business environment in the countries of Visegrad group. Procedia Economics and Finance 26 (2015) 423-430.

[9] Gaganis, C., Pasiouras, F., Voulgari, F. Culture, business environment and SMEs' profitability: Evidence from European Countries. Economic Modelling 78 (2019) 275-292.

[10] Liang, S., Shen, T. Spatial spillover effects of economic association and growth of countries along the China-Indochina Peninsula Economic Corridor. Asia-Pacific Economic Review 5 (2019) 24-31.

[11] Holden, C. Graduated sovereignty and global governance gaps: Special economic zones and the illicit trade in tobacco products. Political Geography 59 (2017) 72-81.

[12] Krishnashamy, K., Shepherd, C., Or. Observations of illegal wildlife trade in Boten, a Chinese border town with a specific economic zone in northern Lao PDR. Global Ecology and Conservation 14 (2018) e00390. 